\title{
Paclitaxel and ceramide synergistically induce cell death with transient activation of EGFR and ERK pathway in pancreatic cancer cells
}

\author{
LIHUA QIU ${ }^{1,2}$, CHANGLIN ZHOU $^{2}$, YUN SUN $^{1}$, WEN DI $^{1}$, ERICA SCHEFFLER ${ }^{2}$, SARAH HEALEY $^{2}$, \\ HAROLD WANEBO $^{3}$, NICOLA KOUTTAB ${ }^{3}$, WENMING CHU ${ }^{4}$ and YINSHENG WAN ${ }^{2}$ \\ ${ }^{1}$ Department of OB/GYN, Renji Hospital, Shanghai Jiaotong University, Shanghai 200001, P.R. China; \\ ${ }^{2}$ Department of Biology, Providence College, Providence, RI 02918; ${ }^{3}$ Department of Surgery, \\ Roger Williams Medical Center, Providence, RI 02908; ${ }^{4}$ Department of Immunology, \\ Brown University, Providence, RI 02903, USA
}

Received March 27, 2006; Accepted June 10, 2006

\begin{abstract}
The molecular and cellular mechanism of the development of pancreatic cancer is under constant and intensive study, and yet the cure is still out of reach. While surgical treatment is optional, conventional chemotherapy or chemo-radiotherapy remains the best choice. Among others, paclitaxel is proven to be a popular and, to a certain extent, effective chemotherapy agent. We proposed that the combination of paclitaxel and membrane permeable ceramide would enhance the fatality of cancer cells, and reported that the combination increased cell death of both head and neck and leukemic cancer cells. In this study, we treated pancreatic cancer cells (L3.6 cells) with paclitaxel and ceramide at the concentrations of clinical relevance, and treatment was then followed up with an investigation of the molecular mechanism of the synergism of paclitaxel and ceramide. The results of Western blot analysis indicated that the combo synergistically induced ERK and JNK phosphorylation, but not p38 and Akt phosphorylation. We also found that the combination (combo) induced EGFR phosphorylation in a synergistic manner. Furthermore, we observed that paclitaxel, ceramide, or combo-induced EGFR phosphorylation was inhibited by EGFR inhibitor, PD153035, while paclitaxel, ceramide, or combo-induced JNK and ERK phosphorylation was blocked by EGFR inhibitor, PD153035 and ERK inhibitor, U126. Taken together, our results
\end{abstract}

Correspondence to: Dr Wen Di, Department of OB/GYN, Renji Hospital, Shanghai Jiaotong University, Shanghai 200001, P.R. China

E-mail: diwen163@163.com

Dr Yinsheng Wan, Department of Biology, Providence College, 549 River Ave., Providence, RI 02918, USA

E-mail: yswan@providence.edu

Key words: pancreatic cancer, paclitaxel, ceramide, combination demonstrated that the combination of paclitaxel and ceramide synergistically induced pancreatic cancer cell death through differential activation of EGFR-mediated MAP kinases. EGFR and ERK inhibitors may further enhance the paclitaxel and ceramide effect.

\section{Introduction}

With its mortality rate close to $100 \%$, pancreatic cancer has recently gained an unprecedented amount of attention. In the United States it is the fourth most frequent cause of cancer mortality and in Japan it ranks as the fifth most common cause of death from cancer $(1,2)$. Pancreatic cancer remains a challenging disease with poor prognosis mainly due to the advanced stage of the disease by the time of presentation, the early systemic dissemination, and its extraordinary local tumor progression (3). Surgery has little to offer in the improvement of the curative percentage of disease. Some progress has been made, however, in the medical management of pancreatic cancer with the introduction and use of new chemical agents in addition to combined chemotherapy and chemoradiotherapy. Various strategies of gene therapy, antiangiogenic treatments, immunotherapy, and signal-transduction inhibition are also in preclinical development (4).

Pancreatic carcinogenesis is driven by multiple genetic and epigenetic changes. Cellular signaling research has unraveled various targets that could be intervened in vitro and in vivo. The epidermal growth factor receptor (EGFR) and its downstream signaling pathways, Ras-Raf-MEK-ERK axis, knowingly play important roles in pancreatic cancer development. The phosphoinositol 3 kinase (PI3K)/Akt and the nuclear factor kappa B $(\mathrm{NF}-\mathrm{\kappa} \mathrm{B})$ pathways control both the proliferation of and the resistance to the apoptosis of pancreatic cancer. The role of cyclooxygenase (COX) and lipoxygenase (LOX) in the development of pancreatic cancer has recently been revealed. The elucidation of these molecular events has led to several distinct therapeutic advances, including therapies that target EGFR, the Ras-Raf-MEK-ERK axis, and the COX-2 and LOX pathways, among others. Many novel agents have 
been developed and are undergoing clinical investigation, such as monoclonal antibodies against EGFR, tyrosine kinase inhibitors, farnesyl transferase inhibitors, Bay43-9006, CI-1040, CCI-779, celecoxib, and LY293111 (5). Matrix metalloproteinase inhibitors, farnesyl transferase inhibitors, epidermal growth factor receptor inhibitors, including monoclonal antibodies and tyrosine kinase inhibitors, cyclooxygenase- 2 inhibitors, Cyclooxygenase (COX)-2 inhibitor, and trypsin inhibitor have all been found to inhibit both the initiation and post-initiation phases of pancreatic carcinogenesis in rat models (6) as well as other models (7).

While signal transduction research ushered a new promise for treatment, many questions remain unresolved. The specificity of the inhibitors remains an issue of hot debate. Conventional chemotherapy still retains its utilization. Paclitaxel, one of the chemotherapeutic agents used in the treatment of recalcitrant ovarian and breast cancers, as well as other neoplasms, is being used for the treatment of pancreatic cancer. While the mechanism of combinatory chemotherapy continues to be elucidated, the beneficial effect of such practice is observed in clinics. We previously hypothesized that the lipid second messenger, ceramide, and microtubule-directed chemotherapeutic agents may engage in converging pathways as a means of inducing apoptosis. Our studies demonstrated that simultaneous treatment of human leukemic cells and head and neck squamous carcinoma cell line with paclitaxel and ceramide enhanced paclitaxel-induced cell growth inhibition $(8,9)$.

In this study, we used paclitaxel, ceramide, and a combination to treat pancreatic cancer cells and found that as previously reported in other cancer cell types, paclitaxel and ceramide synergistically induced cell death.

\section{Materials and methods}

Cell culture. L3.6 cells, a pancreatic cancer cell line, obtained from M.D. Anderson Cancer Center in Houston, were maintained in a Dulbecco's modified Eagle's medium (DMEM) (Sigma) supplemented with a $10 \%$ fetal bovine serum (Hyclone), penicillin/streptomycin (1:100, Sigma), and $4 \mathrm{mM}$ L-glutamine in a humid atmosphere incubator with $5 \% \mathrm{CO}_{2}$ at $37^{\circ} \mathrm{C}$. Cells were reseeded twice a week at a density of $0.2 \times 10^{6}$ cells $/ \mathrm{ml}$ with fresh complete culture medium. Unless otherwise indicated, cultures were grown to $70-80 \%$ confluence and then serum-starve overnight in serum-free DMEM medium prior to treatment. When inhibitors were used, cells were pretreated for $2 \mathrm{~h}$ prior to stimulation with the indicated concentration of inhibitor, which remained in the medium for the duration of the experiment.

Reagents. Paclitaxel, ceramide, and anti- $\beta$-actin were from Sigma. Human EGF was from BD Bioscience. Anti-phosphoEGFR (Tyr1068), phospho-p44/42 MAP kinase, phosphoSAPK/JNK (Thr183/Tyr185), phospho-p38 MAPK (Thr180/ Tyr182), phospho-Akt (Ser473), p44/42 MAP kinase, SAPK/ JNK, p38 MAP kinase and Akt antibody were from Cell Signaling. Anti-EGFR (1005), goat anti-rabbit IgG-HRP, and goat anti-mouse IgG-HRP antibody, and protein A/G plusagarose (sc-2003) were from Santa Cruz Biotechnology. Antisurvivin antibody was from Novus Biologicals. PD153035, U126, and JNK inhibitor I were from Calbiochem.
Treatment. EGF, paclitaxel, and ceramide solutions were diluted in DMEM medium without serum to final concentrations of $100 \mathrm{ng} / \mathrm{ml}, 6 \mu \mathrm{g} / \mathrm{ml}$ and $5 \mu \mathrm{g} / \mathrm{ml}$, respectively. In the time-dependent experiments, L3.6 cells were treated with $100 \mathrm{ng} / \mathrm{ml}$ of EGF, $6 \mu \mathrm{g} / \mathrm{ml}$ of paclitaxel, $5 \mu \mathrm{g} / \mathrm{ml}$ of ceramide, or their combination, and harvested at 5, 15, 30, 60 , and $120 \mathrm{~min}$ after treatment. In experiments for exploration of signaling pathways, L3.6 cells were treated with $6 \mu \mathrm{g} / \mathrm{ml}$ of paclitaxel, $5 \mu \mathrm{g} / \mathrm{ml}$ of ceramide, or their combination in the presence and absence of PD153035 $(20 \mu \mathrm{M})$, JNK inhibitor I $(25 \mu \mathrm{M})$, and $\mathrm{U} 126(25 \mu \mathrm{M})$ for $30 \mathrm{~min}$. Cell morphological changes were microscopically photographed at $12 \mathrm{~h}$ post treatment. Survivin expression was analyzed by Western blotting described below at $12 \mathrm{~h}$ post treatment.

Western blot analysis. As described previously $(10,11)$, cells with and without treatment were washed with cold PBS and harvested by scraping into $0.2 \mathrm{ml}$ RIPA buffer containing $50 \mathrm{mM}$ Tris- $\mathrm{HCl}$ (pH 7.4), $150 \mathrm{mM} \mathrm{NaCl}, 1 \% \mathrm{NP} 40,1 \mathrm{mM}$ EDTA, $0.25 \%$ Sodium Deoxycholate, $1 \mathrm{mM} \mathrm{NaF}, 10 \mu \mathrm{M}$ $\mathrm{Na}_{3} \mathrm{VO}_{4}, 1 \mathrm{mM}$ phenylmethylsulfonyl fluoride, and protease inhibitor cocktail $(10 \mu \mathrm{g} / \mathrm{ml}$ leupeptin, $10 \mu \mathrm{g} / \mathrm{ml}$ aprotinin, and $1 \mu \mathrm{M}$ pepstatin). Cell lysates were incubated on ice for $30 \mathrm{~min}$. After centrifugation at 14,000 rpm for $10 \mathrm{~min}$, protein concentrations were determined by Bradford assay (Bio-Rad, Hercules, CA). Proteins $(50 \mu \mathrm{g})$ were denatured in $2 \mathrm{X}$ SDSPAGE sample buffer for $5 \mathrm{~min}$ at $95^{\circ} \mathrm{C}$. The proteins were separated by $12 \%, 10 \%$, or $7.5 \%$ SDS-PAGE and electrotransferred to Immobilon-P membrane (Millipore, Bedford, $\mathrm{MA}$ ) for $2 \mathrm{~h}$ at $4^{\circ} \mathrm{C}$. Non-specific binding was blocked with $10 \%$ dry milk in TBST $(20 \mathrm{mM}$ Tris- $\mathrm{HCl}, \mathrm{pH} 7.4,137 \mathrm{mM}$ $\mathrm{NaCl}, 0.01 \%$ Tween-20) for $1 \mathrm{~h}$ at room temperature. With constant shaking, the membranes were incubated in primary antibodies in dilution buffer (2\% BSA in TBST) overnight at $4^{\circ} \mathrm{C}$. After washing with TBST three times, the membranes were incubated in secondary antibodies at room temperature for $1 \mathrm{~h}$ with constant shaking. The expression of targeted proteins was detected by ECL kit (Amersham Biosciences) following manufacturer's instructions and visualized by autoradiography with Hyperfilm.

Immunoprecipitation. As described previously (12), cell lysate preparation was performed as described above. Cell lysates were cleared by centrifugation at 14,000 rpm for $10 \mathrm{~min}$. Proteins in the lysate supernatants were immunoprecipitated by overnight incubation with anti-EGFR antibodies at $4^{\circ} \mathrm{C}$, followed by $40 \mu \mathrm{l}$ of protein A/G plus-agarose beads for $2 \mathrm{~h}$. Immunoprecipitates were washed three times with $500 \mu 1$ of RIPA buffer. Then immune complexes were released by incubation in $2 \mathrm{X}$ SDS-PAGE sample buffer at $95^{\circ} \mathrm{C}$ and were subjected to SDS-PAGE on 4-20\% gels and subsequent immunoblot analysis.

\section{Results}

Paclitaxel and ceramide synergistically induced cell death in human L3 .6 pancreatic cancer cells. Our previous studies have shown that combination of paclitaxel and ceramide synergistically induced cell death in leukemic and head and neck cancer cells (8). We propose that this synergistic effect occurs in pancreatic cancer cells as well. In this study, we 


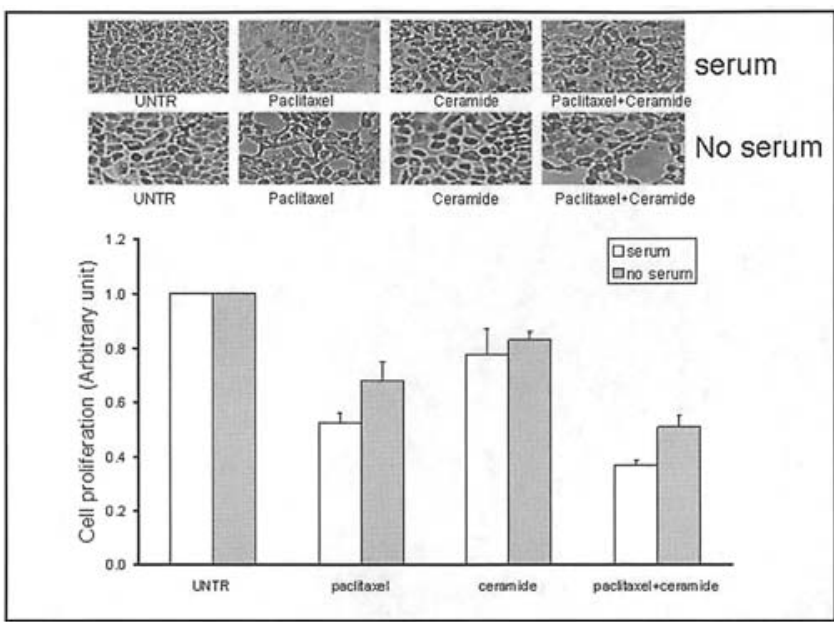

Figure 1. Paclitaxel and ceramide synergistically induced cell death in human L3.6 pancreatic cancer cells. L3.6 cells were cultured in 6-well plates, and treated with paclitaxel $(6 \mu \mathrm{g} / \mathrm{ml})$, ceramide $(5 \mu \mathrm{g} / \mathrm{ml})$ or combo with or without serum starvation. Cell densities and morphologies were photographed at $12 \mathrm{~h}$ post treatment. The quantitative results are shown as a histogram. Each bar is the mean \pm SD from six independent microscopic fields of a representative experiment.

first examined whether paclitaxel and ceramide have synergistic effect on cell death. L3.6 cells were cultured in 6-well plates, and treated with paclitaxel $(6 \mu \mathrm{g} / \mathrm{ml})$, ceramide $(5 \mu \mathrm{g} / \mathrm{ml})$, or a combo with or without serum starvation. Microscopic data after $12 \mathrm{~h}$ of treatment indicated that while paclitaxel or ceramide alone induced cell death, a paclitaxel and ceramide combo had a synergistic effect on cell death in human L3.6 cells (Fig. 1).

Paclitaxel and ceramide synergistically induced ERK and JNK but not p38 and Akt activation in human L3.6 cells. It has been shown that paclitaxel and ceramide induce cell death through various pathways (13-17). Existing data indicate that the mitogen-activated protein (MAP) kinase pathway is related to drug-induced cell death (18). In order to further understand the mechanism of the synergism, namely, the pathways associated with the cell death, we then examined whether paclitaxel and ceramide differentially activate MAP kinases in human L3.6 cells. Cells were deprived of serum overnight and treated with paclitaxel $(6 \mu \mathrm{g} / \mathrm{ml})$, ceramide $(5 \mu \mathrm{g} / \mathrm{ml})$, or a combination. Cell lysates were collected at 30,60 , and 120 min post treatment. Western blot analysis indicated that paclitaxel and ceramide remarkably induced ERK and JNK activation, while only marginally inducing p38 and Akt activation (Fig. 2). Paclitaxel-induced ERK and JNK activation peaked at $60 \mathrm{~min}$ and the activities returned to basal level within 120 min of treatment. Ceramide-induced ERK and JNK activation peaked at $30 \mathrm{~min}$ and the activities returned to basal level within $120 \mathrm{~min}$. The combination of paclitaxel and ceramide showed the strongest activation of both ERK and JNK at 30 min post treatment. As expected, total JNK, ERK, p38, and Akt remained unchanged over the course of drug treatment.

Paclitaxel and ceramide synergistically induced phosphorylation of EGFR in human L3.6 cells. Growth factor receptors are activated through autophosphorylation upon ligand binding.

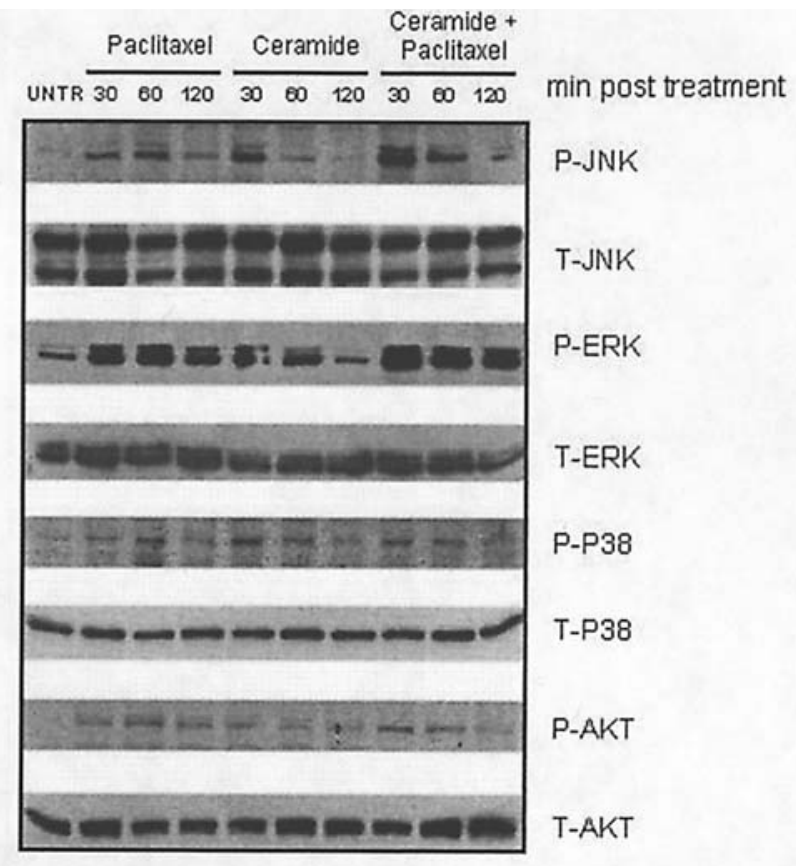

Figure 2. Paclitaxel and ceramide synergistically induced ERK and JNK but not p38 and AKT activation in human L3.6 cells. Cells were deprived of serum overnight and treated with $6 \mu \mathrm{g} / \mathrm{ml}$ of paclitaxel, $5 \mu \mathrm{g} / \mathrm{ml}$ of ceramide, or combo. Cell lysates were collected at 30,60 and 120 min post treatment. JNK, ERK1/2, P38, and AKT phosphorylation were analyzed by Western blotting.

The downstream MAP kinases are subsequently activated. To determine whether Paclitaxel and ceramide-induced MAP kinase activation are due to the activation of EGFR, human L3.6 cells were cultured and deprived of serum overnight. The cells were then treated with paclitaxel $(6 \mu \mathrm{g} / \mathrm{ml})$, ceramide $(5 \mu \mathrm{g} / \mathrm{ml})$, or combo and harvested at certain time-points for further analysis. Western blot analysis using antibody recognizing phopsho-EGFR indicated that paclitaxel induced EGFR tyrosine phosphorylation in a time-dependent manner. The phosphorylation started $30 \mathrm{~min}$ post treatment, and the activity peaked at $60 \mathrm{~min}$ and then returned to basal level within 120 min. Likewise, ceramide induced EGFR activation in a time-dependent manner, the activity peaked at $30 \mathrm{~min}$ and then returned to basal level within $120 \mathrm{~min}$. Interestingly, the combination of paclitaxel and ceramide induced EGFR phosphorylation in a synergistic manner. The phosphorylation started at $30 \mathrm{~min}$, peaked at $60 \mathrm{~min}$, and then returned to basal level within $120 \mathrm{~min}$ (Fig. 3B). As predicted, EGF $(100 \mathrm{ng} / \mathrm{ml})$ itself induced EGFR phosphorylation in a timedependent manner. The phosphorylation started earlier, peaked at $5 \mathrm{~min}$, and then returned to basal level within $120 \mathrm{~min}$ (Fig. 3A). Meanwhile, we detected the effect of EGFR inhibitor on paclitaxel, ceramide, or combo-induced EGFR signaling. Human L3.6 cells were pretreated with EGFR inhibitor, PD153035 $(20 \mu \mathrm{M})$ for $2 \mathrm{~h}$, and then treated with paclitaxel $(6 \mu \mathrm{g} / \mathrm{ml})$, ceramide $(5 \mu \mathrm{g} / \mathrm{ml})$, or combo for $30 \mathrm{~min}$. As shown in Fig. 3C, pretreatment of PD153035 inhibited paclitaxel, ceramide, or combo-induced EGFR phosphorylation. In all experiments, as expected, total EGFR remained unaltered.

EGFR and ERK inhibitor blocked ERK and JNK activation induced by paclitaxel, ceramide, or combo in human L3.6 cells. The above data indicated that PD153035 dramatically 
A

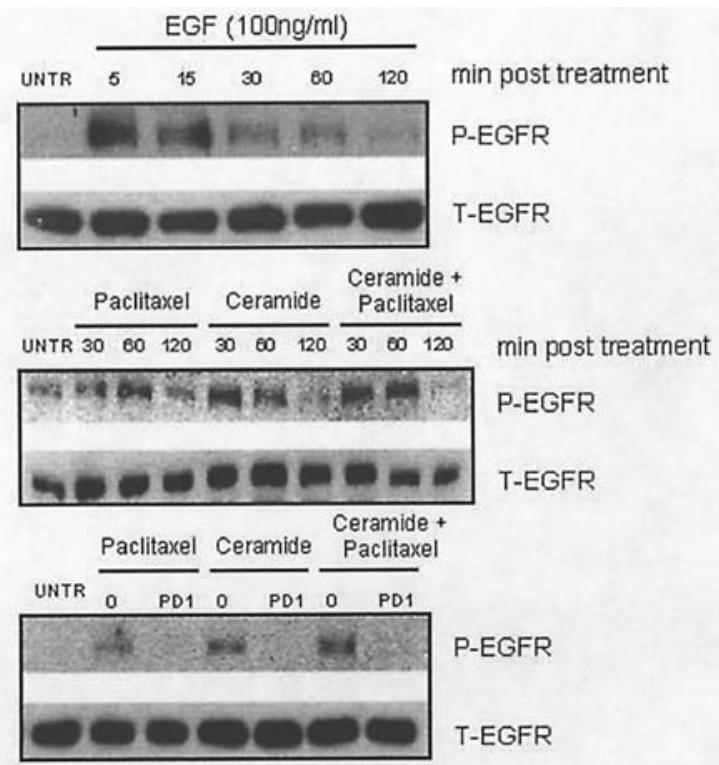

Figuer 3. Paclitaxel and ceramide synergistically induced phosphorylation of EGFR in human L3.6 cells. Human L3.6 cells were deprived of serum overnight and treated with $100 \mathrm{ng} / \mathrm{ml}$ of EGF, and harvested at 5, 15,30, 60, and 120 min post treatment (A). Cells were deprived of serum overnight and treated with $6 \mu \mathrm{g} / \mathrm{ml}$ of paclitaxel, $5 \mu \mathrm{g} / \mathrm{ml}$ of ceramide, or combo, and harvested at 5, 15,30,60 and 120 min post treatment (B). Cells were pretreated with $20 \mu \mathrm{M}$ of PD153035 (PD1) for $2 \mathrm{~h}$, and then treated with paclitaxel $(6 \mu \mathrm{g} / \mathrm{ml})$, ceramide $(5 \mu \mathrm{g} / \mathrm{ml})$, or combo for $30 \mathrm{~min}(\mathrm{C})$. EGFR phosphorylation was analyzed by Western blotting.

inhibited paclitaxel, ceramide, or combo-induced EGFR phosphorylation. Next we examined whether EGFR inhibitor inhibits paclitaxel, ceramide, or combo-induced downstream ERK and JNK activation. Human L3.6 cells were pretreated with EGRF inhibitor, PD153035 $(20 \mu \mathrm{M})$ for $2 \mathrm{~h}$, and were then treated with paclitaxel, ceramide, or combo. Cells were collected 30 min post treatment. Downstream component ERK and JNK activation was also inhibited (Fig. 4A). We further pretreated the L3.6 cells with JNK and ERK inhibitor, JNKI $(25 \mu \mathrm{M})$ and $\mathrm{U} 126(25 \mu \mathrm{M})$, and then exposed the cells with paclitaxel, ceramide, or combo for $30 \mathrm{~min}$. Western blot analysis showed that JNK inhibitor did not inhibit paclitaxel, ceramide, or combo-induced JNK and ERK activation, whereas ERK inhibitor inhibited paclitaxel, ceramide, or comboinduced JNK and ERK activation (Fig. 4B).

Paclitaxel and ceramide synergistically induced survivin degradation in human L3.6 cells. Anti-apoptosis proteins (IAPs) are important for establishing a balance of the number of cells that undergo either apoptosis or survival. Survivin, as a member of IAP family, is over-expressed in various types of cancer (19). Targeting of survivin is becoming an option for in vitro testing (20-23). A recent report that paclitaxel can transiently induce the expression of survivin, in addition to the possibility that it can protect paclitaxel-induced cell death, further supports that notion that survivin should be targeted for cancer treatment (24). We treated L3.6 cells with or without serum, and then exposed the cells with paclitaxel, ceramide, or combo for $12 \mathrm{~h}$. Western blot analysis indicated that the expression of survivin protein was low in serum-starved cells. While paclitaxel or ceramide alone mildly induced

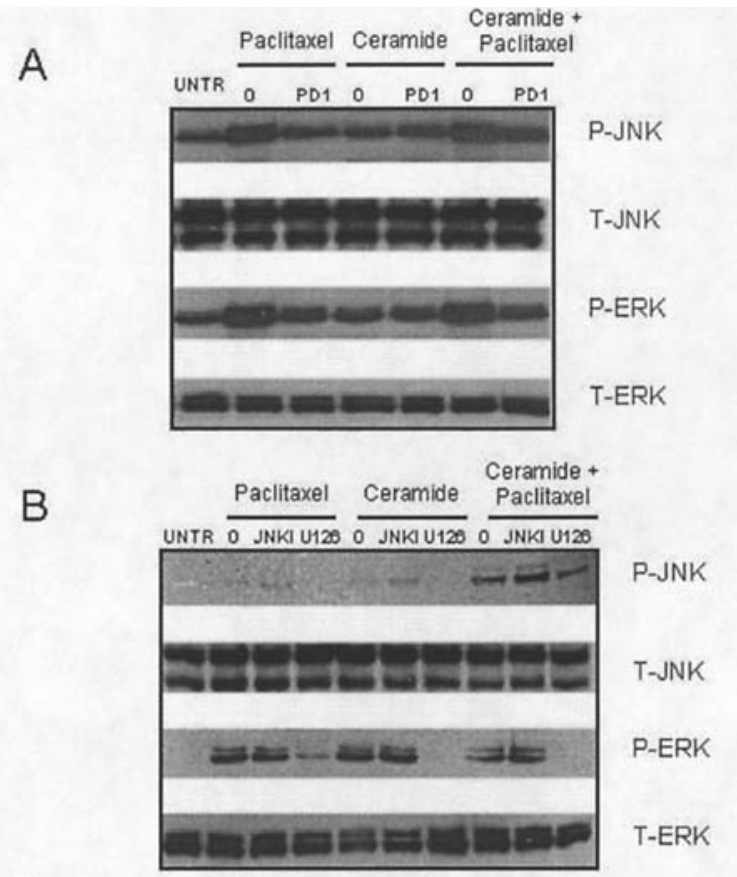

Figure 4. EGFR and ERK inhibitor blocked ERK and JNK activation induced by paclitaxel, ceramide, or combo in human L3.6 cells. Human L3.6 cells were deprived of serum overnight and pretreated with $20 \mu \mathrm{M}$ of PD153035 (PD1), and then exposed to $6 \mu \mathrm{g} / \mathrm{ml}$ of paclitaxel, $5 \mu \mathrm{g} / \mathrm{ml}$ of ceramide, or combo for $30 \mathrm{~min}$ (A). Cells were pretreated with $25 \mu \mathrm{M}$ of JNKI or $25 \mu \mathrm{M}$ of $\mathrm{U} 126$ for $2 \mathrm{~h}$, and then exposed to paclitaxel $(6 \mu \mathrm{g} / \mathrm{ml})$, ceramide $(5 \mu \mathrm{g} / \mathrm{ml})$, or combo for $30 \mathrm{~min}$ (B). JNK and AKT phosphorylation were analyzed by Western blotting.

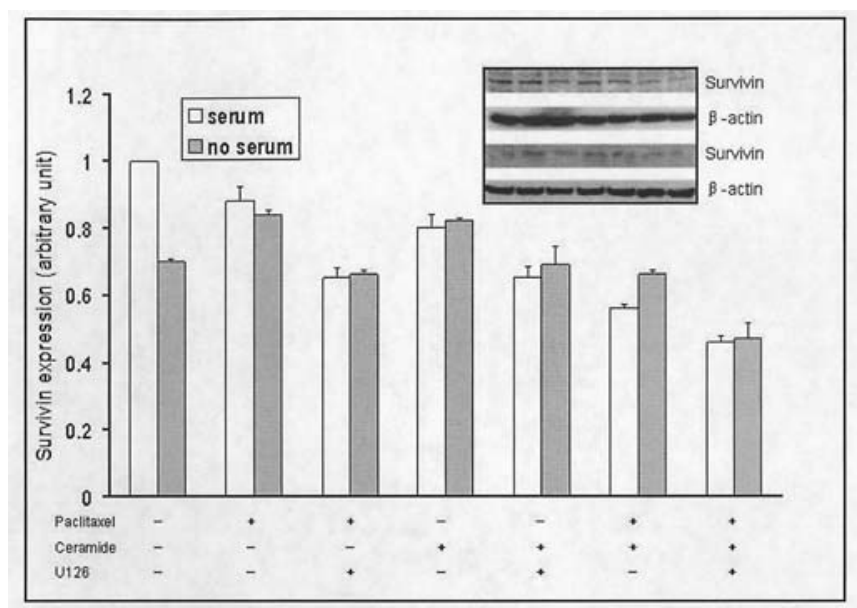

Figure 5. Paclitaxel and ceramide synergistically induced survivin degradation in human L3.6 cells. Human L3.6 cells were deprived of serum overnight or cultured in DMEM with serum, and treated with $6 \mu \mathrm{g} / \mathrm{ml}$ of paclitaxel, $5 \mu \mathrm{g} / \mathrm{ml}$ of ceramide, or combo alone or in combination with $25 \mu \mathrm{M}$ of U126 for $12 \mathrm{~h}$. Survivin expression was analyzed by Western blotting (insert). The quantitative results are shown as a histogram. Each bar is the mean \pm SD from three independent experiments.

survivin degradation, the combination of paclitaxel and ceramide synergistically induced survivin degradation with or without serum. Pretreatment with ERK inhibitor, U126 $(25 \mu \mathrm{M})$, with or without serum starvation enhanced paclitaxel, ceramide, or combo-induced survivin degradation (Fig. 5). 
A

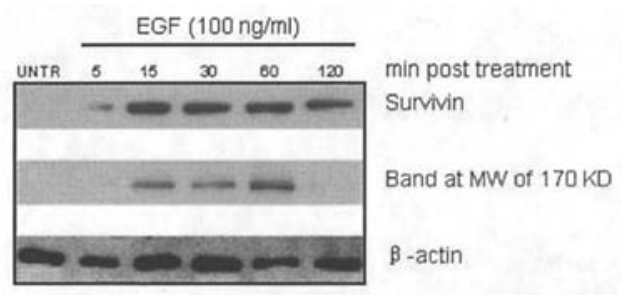

B

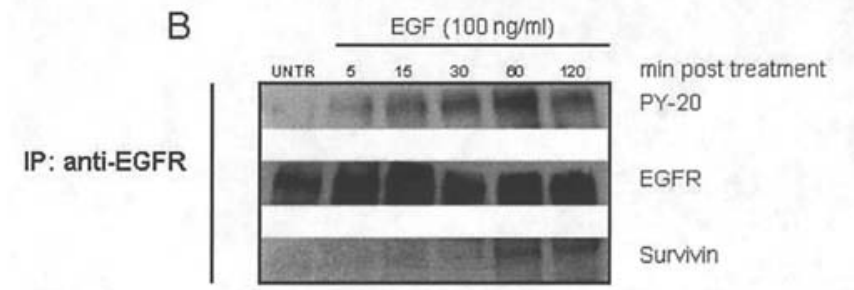

Figure 6. EGF induced survivin expression and survivin was physically associated with EGFR in human L3.6 cells. Human L3.6 cells were deprived of serum overnight and treated with $100 \mathrm{ng} / \mathrm{ml}$ of EGF, and harvested at $5,15,30,60$, and 120 min post treatment. Survivin expression was analyzed by Western blotting (A). Cells were exposed to $100 \mathrm{ng} / \mathrm{ml}$ of EGF and harvested at 5, 15, 30,60, and 120 min post treatment. Cell lysates were incubated with the anti-EGFR antibody, and immune complexes were precipitated, as described previously, and blotted with PY-20 antibody directed against phosphotyrosine, and by antibodies directed against EGFR and survivin $(\mathrm{B})$.

EGF induced survivin expression and survivin was physically associated with EGFR in human L3.6 cells. To further study the role of EGFR in survivin expression and cell survival, human L3.6 cells were deprived of serum for $12 \mathrm{~h}$ and were subsequently treated with $100 \mathrm{ng} / \mathrm{ml}$ of EGF. The cells were then harvested at 5, 15, 30, 60, and 120 min post treatment. Western blot analysis indicated that EGF induced expression of survivin in L3.6 cells. The survivin expression started at $15 \mathrm{~min}$ and the level of survivin remained elevated for several hours (Fig. 6A). Interestingly, while anti-survivin antibody was used to monitor survivin expression, a band was seen at the molecular weight of $170 \mathrm{kDa}$ at 15,30 , and $60 \mathrm{~min}$. We proposed that it is an EGFR band, and EGFR activation leads to the physical association of EGFR with survivin, therefore the anti-survivin antibody detects the EGFR-survivin complex. To test this hypothesis, we treated cells with $100 \mathrm{ng} / \mathrm{ml}$ of EGF and collected cell lysates at 5, 15, 30, 60, and $120 \mathrm{~min}$ post treatment. Immunoprecipitation was performed with anti-EGFR antibody. The immunoprecipitates were subjected to SDS-PAGE and Western blot analysis by PY-20 antibody directed against phosphotyrosine, as well as antibodies directed against EGFR and survivin. The results showed that the survivin band appeared 15 min post EGF treatment, and that the signal peaked at $60 \mathrm{~min}$ and remained elevated for $2 \mathrm{~h}$. EGFR phosphorylation was also detectable in a time-dependent manner (Fig. 6B).

EGFR or ERK inhibitor enhanced paclitaxel, ceramide, or combo-induced cell death in human L3.6 cells. The above data indicated that paclitaxel, ceramide, or combo differentially induced ERK and JNK activation in human L3.6 cells. Paclitaxel, ceramide, or combo-induced activation of ERK and JNK is also mediated by EGFR signaling. Above data also demonstrated that EGF induces survivin expression. Ceramide

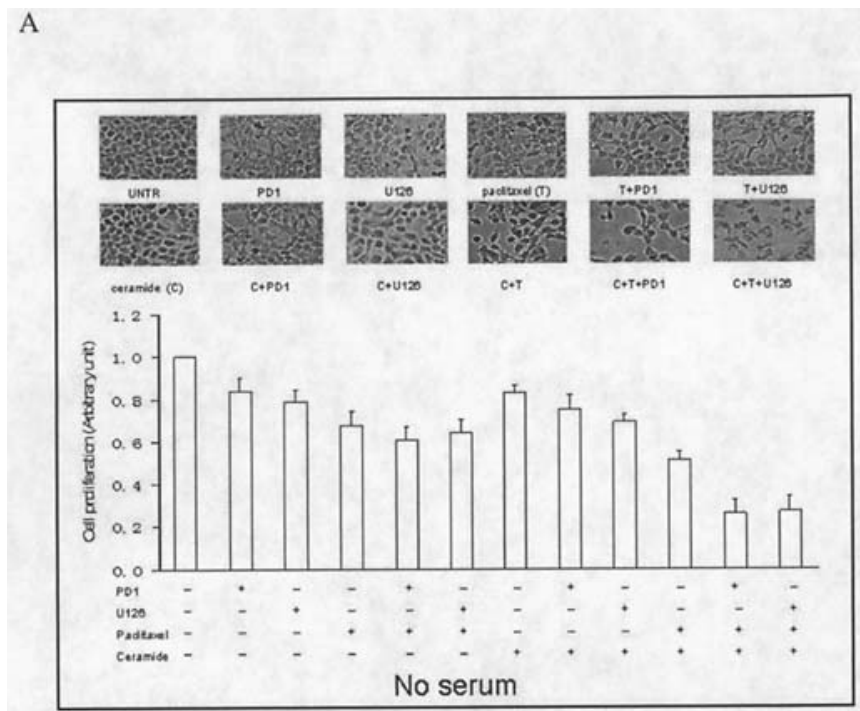

B

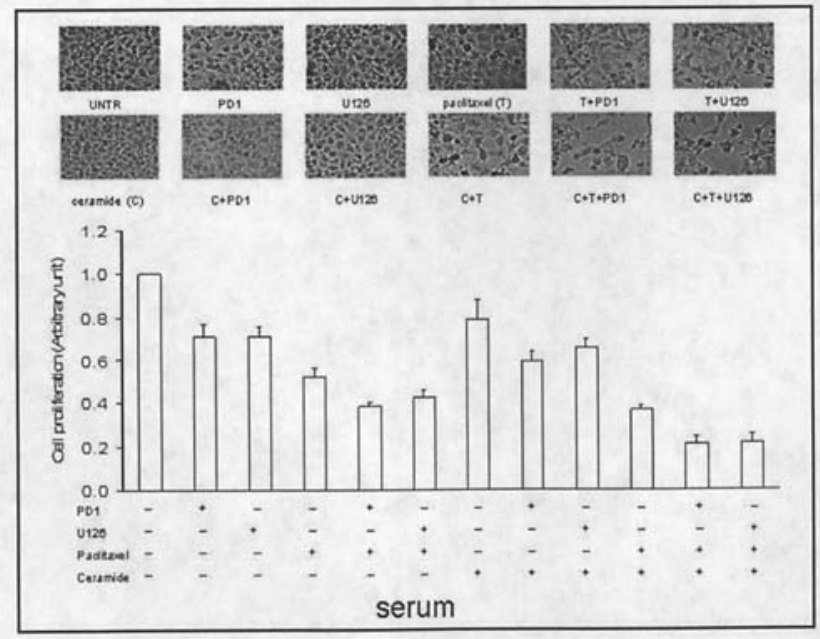

Figure 7. EGFR or ERK inhibitor enhanced paclitaxel, ceramide, or comboinduced cell death in human L3.6 cells. Human L3.6 cells were deprived of serum overnight, and treated with $6 \mu \mathrm{g} / \mathrm{ml}$ of paclitaxel (T), $5 \mu \mathrm{g} / \mathrm{ml}$ of ceramide (C), or combo $(\mathrm{C}+\mathrm{T})$ alone or in combination with $20 \mu \mathrm{M}$ of EGFR inhibitor, PD153035 (PD1) or $25 \mu \mathrm{M}$ of ERK inhibitor, U126 for $12 \mathrm{~h}$ (A). Cells were cultured in DMEM with serum, and exposed to paclitaxel $(6 \mu \mathrm{g} / \mathrm{ml})$, ceramide $(5 \mu \mathrm{g} / \mathrm{ml})$, or combo alone or in combination with EGFR inhibitor, PD153035 $(20 \mu \mathrm{M})$ or ERK inhibitor, U126 $(25 \mu \mathrm{M})$ for $12 \mathrm{~h}$ (B). Cell densities and morphologies were photographed. The quantitative results are shown as a histogram. Each bar is the mean \pm SD from six independent microscopic fields of a representative experiment.

is an option to enhance the efficacy of paclitaxel. Could we add EGFR or ERK inhibitor to the combo to further enhance the efficacy of paclitaxel? We treated human L3.6 cells with or without serum, and then exposed the cells with paclitaxel $(6 \mu \mathrm{g} / \mathrm{ml})$, ceramide $(5 \mu \mathrm{g} / \mathrm{ml})$, or combo alone or in combination with EGFR inhibitor, PD153035 $(20 \mu \mathrm{M})$, or ERK inhibitor, U126 $(25 \mu \mathrm{M})$ for $12 \mathrm{~h}$. Microscopic data indicated that the cell proliferation and survival rate caused by the combination of inhibitors with paclitaxel, ceramide, or combo was significantly reduced as compared with that caused by paclitaxel, ceramide, or combo alone (Fig. 7). 


\section{Discussion}

It has been shown that both paclitaxel and ceramide enhance cell growth inhibition and apoptotic cell death $(25,26)$. Previous data indicated that concurrent paclitaxel and radiation demonstrate locoregional activity in pancreatic cancer (27). However, there have been few investigations into the effects of ceramide on the cell growth of pancreatic cancer. In the present study, we found that ceramide also induced cell death in the L3.6 pancreatic cancer cell cells, and the combination of paclitaxel and ceramide had synergistical effects on cell death (Fig. 1).

Paclitaxel and ceramide are implicated in the regulation of various signaling pathways leading to proliferation, differentiation, or apoptosis (28-32). Existing data indicated that the MAP kinase pathway is related with paclitaxel or ceramide induced cell death in three different human cancer cell lines: HeLa cervical carcinoma, MCF7 breast cancer cells, and A431 squamous carcinoma cells (18). The mitogen-induced ERK MAPKs were linked to cell proliferation and survival, whereas the stress-activated MAPKs, p38, and JNK were connected with apoptosis. Here, we found that paclitaxel and ceramide alone induced ERK and JNK activation, while the combo synergistically induced the activation of ERK and JNK (Fig. 2). Our results suggest that the combo-induced synergistical effect on cell death is mediated by ERK and JNK signaling in human L3.6 cells.

Our present data also indicated that the combination of paclitaxel and ceramide synergistically transactivated EGFR in a time-dependent manner (Fig. 3B). Activation of the EGFR tyrosine kinase results in the generation of a number of intracellular signals, which culminate in not only cell proliferation, but also in other processes that are crucial to cancer progression, including angiogenesis, metastatic spread, and the inhibition of apoptosis. These events are mediated through various downstream targets of EGFR (e.g. the serine/ threonine kinase Raf and MEK-ERK 1/2). Furthermore, the activation of EGFR results in the activation of the lipid kinase PI3K, generating the second messenger phosphatidylinositol 3,4,5-trisphosphate, which in turn activates Akt $(33,34)$. In the current study, we found EGFR inhibitor, PD153035 inhibited paclitaxel, ceramide, or combo-induced EGFR, JNK, and ERK activation (Figs. 3C and 4A), which confirmed that drug-induced JNK and ERK activation are dependent on activation of their upstream target, EGFR. Moreover, we demonstrated that drug-induced activation of JNK and ERK was inhibited by an ERK inhibitor, but not a JNK inhibitor (Fig. 4B). Therefore, we suggest that drug-induced JNK activation is caused by ERK activation, and EGFR/ERK signaling is important in the action of paclitaxel, ceramide, or combo in human L3.6 cells.

The balance between apoptosis and anti-apoptosis signaling pathways plays a role in the pathogenesis of a variety of cancers (35). Survivin is a recently characterized and novel member of the inhibitor of apoptosis (IAP) protein family. Undetectable in most normal tissues but highly expressed in cancer, survivin has been shown to be associated with carcinogenesis, cancer progression, poor prognosis, drug resistance, and short patient survival (19). Our results have shown that survivin was over-expressed in human L3.6 cells. Serum withdrawing and chemotherapeutic agents could degrade the expression of survivin. While paclitaxel or ceramide alone had mild effect on survivin expression, the combo remarkably downregulated the level of survivin (Fig. 5). We also demonstrated that the inhibition of ERK pathway led to degradation of survivin (Fig. 5). Furthermore, our immunoprecipitation result indicated that survivin expression was associated with EGFR activation (Fig. 6B). It has been demonstrated that inhibition of survivin expression and/or function in tumor cells by survivin antisense or dominant-negative mutants triggers apoptosis (36-40). Taken together, we hypothesize that inhibition of EGFR/ERK signaling might enhance the effect of paclitaxel, ceramide, or combo by down-regulation of survivin. We further provide evidence that EGFR inhibitor, PD153035, and ERK inhibitor, U126, enhanced cell death induced by paclitaxel, ceramide, or combo in human L3.6 cells with or without serum starvation (Fig. 7).

In conclusion, we present herein evidence that the combination of paclitaxel and ceramide synergistically induced EGFR activation, leading to JNK and ERK activation, down-regulation of survivin, and cell death in human L3.6 cells. Inhibition of EGFR/ERK signaling transiently activated by drugs further enhanced survivin degradation and druginduced cell death. Our data suggest that the combination of EGFR or ERK inhibitor with combo of paclitaxel and ceramide may yield better clinical outcomes in the treatment of pancreatic cancer.

\section{Acknowledgements}

This research was supported in part by a grant from National Natural Science Foundation of China, a grant from NIH (P20 RR016457 from INBRE Program of the National Center for Research Resources) and a grant for biomedical research from Rhode Island Foundation, and a grant from Slater Center for Environmental Biotechnology.

\section{References}

1. Lowenfels $\mathrm{AB}$ and Maisonneuve P: Epidemiology and prevention of pancreatic cancer. Jpn J Clin Oncol 34: 238-244, 2004.

2. Ghadirian P, Lynch HT and Krewski D: Epidemiology of pancreatic cancer: an overview. Cancer Detect Prev 27: 87-93, 2003.

3. Safioleas MC and Moulakakis KG: Pancreatic cancer today. Hepatogastroenterology 51: 862-868, 2004.

4. MacKenzie MJ: Molecular therapy in pancreatic adenocarcinoma. Lancet Oncol 5: 541-549, 2004.

5. Xiong HQ: Molecular targeting therapy for pancreatic cancer. Cancer Chemother Pharmacol 54: S69-S77, 2004.

6. Nishikawa A, Furukawa F, Lee IS, Tanaka T and Hirose M: Potent chemopreventive agents against pancreatic cancer. Curr Cancer Drug Targets 4: 373-384, 2004.

7. Pino SM, Xiong HQ, McConkey D and Abbruzzese JL: Novel therapies for pancreatic adenocarcinoma. Curr Oncol Rep 6: 199-206, 2004.

8. Mehta S, Blackinton D, Omar I, Kouttab N, Myrick D, Klostergaard $\mathrm{J}$ and Wanebo $\mathrm{H}$ : Combined cytotoxic action of paclitaxel and ceramide against the human Tu138 head and neck squamous carcinoma cell line. Cancer Chemother Pharmacol 46: 85-92, 2000

9. Myrick D, Blackinton D, Klostergaard J, Kouttab N, Maizel A, Wanebo H and Mehta S: Paclitaxel-induced apoptosis in Jurkat, a leukemic $\mathrm{T}$ cell line, is enhanced by ceramide. Leuk Res 23: 569-578, 1999.

10. Qiu L, Wang Q, Di W, Jiang Q, Schefeller E, Derby S, Wanebo H, Yan B and Wan Y: Transient activation of EGFR/AKT cell survival pathway and expression of survivin contribute to reduced sensitivity of human melanoma cells to betulinic acid. Int $\mathbf{J}$ Oncol 27: 823-830, 2005 
11. Qiu L, Di W, Jiang Q, Scheffler E, Derby S, Yang J, Kouttab N, Wanebo H, Yan B and Wan Y: Targeted inhibition of transient activation of the EGFR-mediated cell survival pathway enhances paclitaxel-induced ovarian cancer cell death. Int J Oncol 27: 1441-1448, 2005

12. Fisher GJ, Talwar HS, Lin J, Lin P, McPhillips F, Wang Z, Li X, Wan Y, Kang S and Voorhees JJ: Retinoic acid inhibits induction of c-Jun protein by ultraviolet radiation that occurs subsequent to activation of mitogen-activated protein kinase pathways in human skin in vivo. J Clin Invest 101: 1432-1440, 1998.

13. Von Haefen C, Wieder T, Essmann F, Schulze-Osthoff K, Dorken B and Daniel PT: Paclitaxel-induced apoptosis in BJAB cells proceeds via a death receptor-independent, caspases-3/-8driven mitochondrial amplification loop. Oncogene 22: 2236-2247, 2003.

14. Pasquier E, Carre M, Pourroy B, Camoin L, Rebai O, Briand C and Braguer D: Antiangiogenic activity of paclitaxel is associated with its cytostatic effect, mediated by the initiation but not completion of a mitochondrial apoptotic signaling pathway. Mol Cancer Ther 3: 1301-1310, 2004.

15. Huang Y, Fang Y, Dziadyk JM, Norris JS and Fan W: The possible correlation between activation of NF-kappaB/IkappaB pathway and the susceptibility of tumor cells to paclitaxelinduced apoptosis. Oncol Res 13: 113-122, 2002.

16. Falluel-Morel A, Aubert N, Vaudry D, Basille M, Fontaine M, Fournier A, Vaudry H and Gonzalez BJ: Opposite regulation of the mitochondrial apoptotic pathway by $\mathrm{C} 2$-ceramide and PACAP through a MAP-kinase-dependent mechanism in cerebellar granule cells. J Neurochem 91: 1231-1243, 2004.

17. Caricchio R, D'Adamio L and Cohen PL: Fas, ceramide and serum withdrawal induce apoptosis via a common pathway in a type II Jurkat cell line. Cell Death Differ 9: 574-580, 2002.

18. Boldt S, Weidle UH and Kolch W: The role of MAPK pathways in the action of chemotherapeutic drugs. Carcinogenesis 23: 1831-1838, 2002.

19. Li F: Survivin study: what is the next wave? J Cell Physiol 197: 8-29, 2003.

20. Facchetti F, Previdi S, Ballarini M, Minucci S, Perego P and La Porta CA: Modulation of pro- and anti-apoptotic factors in human melanoma cells exposed to histone deacetylase inhibitors. Apoptosis 9: 573-582, 2004.

21. Grossman D, McNiff JM, Li F and Altieri DC: Expression and targeting of the apoptosis inhibitor, survivin, in human melanoma. J Invest Dermatol 113: 1076-1081, 1999.

22. Pennati M, Colella G, Folini M, Citti L, Daidone MG and Zaffaroni N: Ribozyme-mediated attenuation of survivin expression sensitizes human melanoma cells to cisplatin-induced apoptosis. J Clin Invest 109: 285-286, 2002.

23. Pennati M, Binda M, De Cesare M, Pratesi G, Folini M, Citti L, Daidone MG, Zunino F and Zaffaroni N: Ribozyme-mediated down-regulation of survivin expression sensitizes human melanoma cells to topotecan in vitro and in vivo. Carcinogenesis 25: 1129-1136, 2004

24. Ling X, Bernacki RJ, Brattain MG and Li F: Induction of survivin expression by taxol (paclitaxel) is an early event, which is independent of taxol-mediated G2/M arrest. J Biol Chem 279: 15196-15203, 2004.

25. Han WS, Yoo JY, Youn SW, Kim DS, Park KC, Kim SY and Kim KH: Effects of C2-ceramide on the Malme-3M melanoma cell line. J Dermatol Sci 30: 10-19, 2002.
26. Jordan MA and Wilson L: Microtubules as a target for anticancer drugs. Nat Rev Cancer 4: 253-265, 2004.

27. Safran H, Moore T, Iannitti D, Dipetrillo T, Akerman P, Cioffi W, Harrington D, Quirk D, Rathore R, Cruff D, Vakharia J, Vora S, Savarese D and Wanebo H: Paclitaxel and concurrent radiation for locally advanced pancreatic cancer. Int J Radiat Oncol Biol Phys 49: 1275-1279, 2001.

28. Bacus SS, Gudkov AV, Lowe M, Lyass L, Yung Y, Komarov AP, Keyomarsi K, Yarden Y and Seger R: Taxol-induced apoptosis depends on MAP kinase pathways (ERK and p38) and is independent of p53. Oncogene 20: 147-155, 2001.

29. Abuharbeid S, Apel J, Zugmaier G, Knabbe C, Sander M, Gilbert S, Czubayko F and Aigner A: Inhibition of HER-2 by three independent targeting strategies increases paclitaxel resistance of SKOV-3 ovarian carcinoma cells. Naunyn Schmiedebergs Arch Pharmacol 371: 141-151, 2005.

30. Allouche M, Bettaieb A, Vindis C, Rousse A, Grignon C and Laurent G: Influence of $\mathrm{Bcl}-2$ overexpression on the ceramide pathway in daunorubicin-induced apoptosis of leukemic cells. Oncogene 14: 1837-1845, 1997.

31. Bieberich E, Hu B, Silva J, MacKinnon S, Yu RK, Fillmore H, Broaddus WC and Ottenbrite RM: Synthesis and characterization of novel ceramide analogs for induction of apoptosis in human cancer cells. Cancer Lett 181: 55-64, 2002.

32. Aoudjit $\mathrm{F}$ and Vuori K: Integrin signaling inhibits paclitaxelinduced apoptosis in breast cancer cells. Oncogene 20: 4995-5004, 2001.

33. Citri A, Kochupurakkal BS and Yarden Y: The achilles heel of ErbB-2/HER2: regulation by the Hsp90 chaperone machine and potential for pharmacological intervention. Cell Cycle 3: 51-60, 2004.

34. Nicosia SV, Bai W, Cheng JQ, Coppola D and Kruk PA: Oncogenic pathways implicated in ovarian epithelial cancer. Hematol Oncol Clin North Am 17: 927-943, 2003.

35. Hussein MR, Haemel AK and Wood GS: Apoptosis and melanoma: molecular mechanisms. J Pathol 199: 275-288, 2003.

36. Li F, Ambrosini G, Chu EY, Plescia J, Tognin S, Marchisio PC and Altieri DC: Control of apoptosis and mitotic spindle checkpoint by survivin. Nature 396: 580-584, 1998.

37. Ambrosini G, Adida C, Sirugo G and Altieri DC: Induction of apoptosis and inhibition of cell proliferation by survivin gene targeting. J Biol Chem 273: 11177-11182, 1998.

38. Grossman D, McNiff JM, Li F and Altieri DC: Expression of the apoptosis inhibitor, survivin, in non-melanoma skin cancer and gene targeting in a keratinocyte cell line. Lab Invest 79: 1121-1126, 1999.

39. Olie RA, Simoes-Wust AP, Baumann B, Leech SH, Fabbro D, Stahel RA and Zangemeister-Wittke U: A novel antisense oligonucleotide targeting survivin expression induces apoptosis and sensitizes lung cancer cells to chemotherapy. Cancer Res 60: 2805-2809, 2000

40. O'Connor DS, Grossman D, Plescia J, Li F, Zhang H, Villa A, Tognin S, Marchisio PC and Altieri DC: Regulation of apoptosis at cell division by $\mathrm{p} 34 \mathrm{cdc} 2$ phosphorylation of survivin. Proc Natl Acad Sci USA 97: 13103-13107, 2000. 